\title{
ANALYSIS ON AIMg 2 AS RSG-GAS CLADDING MATERIAL CORROSION IN CHLORIDE CONTAINING WATER
}

\section{ANALISIS KOROSI TERHADAP MATERIAL AIMg 2 SEBAGAI KELONGSONG BAHAN BAKAR RSG-GAS DALAM AIR MENGANDUNG KLORIDA}

\author{
Febrianto, Sriyono, Geni R Sunaryo \\ Center for Nuclear Reactor Technology and Safety (PTKRN),National Nuclear Energy Agency of Indonesia (BATAN), \\ PUSPIPTEK Area, Building No. 80, Serpong,Tangerang Selatan, Indonesia, 15310 \\ Email: febri@batan.go.id
}

Diterima 17 April 2018, diterima dalam bentuk perbaikan 6 September 2018, disetujui 14 September 2018

\begin{abstract}
CORROSION ANALYSIS ON AIMg 2 AS RSG-GAS CLADDING MATERIAL IN CHLORIDE CONTAINING WATER. The $\mathrm{AIMg}_{2}$ is one of an alluminium alloy that used as cladding material for the RSG GA. Siwabessy (RSG-GAS) research reactor in Serpong, Indonesia. The reactor uses demineralized water as primary coolant with 6.5 to 7.5 of $\mathrm{pH}$. A poor treatment of water in primary coolant can lead to the problem of $\mathrm{AlMg}_{2}$ integrity. The primary coolant concentration of chloride must be lower than $0.0094 \mathrm{ppm}$ to protect cladding corrosion. The purpose of this study is to determine the effect of temperature and chloride ion concentration to AlMg 2 . The method in this research is to observe the corrosion rate for $\mathrm{AMg}_{2}$ material by using Potentiostat. The laboratory experiments were conducted in various temperatures $\left(28,35,40\right.$ and $\left.45^{\circ} \mathrm{C}\right)$ and concentrations of sodium chloride were $0.005,0.010,0.015,0.020$, $0.025,0.030$ and $0.035 \mathrm{ppm}$. The results show the corrosion rates were very small, and the highest corrosion rate occured was $1.23 \times 10^{-3} \mathrm{mpy}$ in $0.035 \mathrm{ppm}$ of $\mathrm{NaCl}$ at $45^{\circ} \mathrm{C}$.
\end{abstract}

Keywords: $\mathrm{AlMg}_{2}$, corrosion, cladding material, chloride ion, temperature, Potensiotat.

\begin{abstract}
ABSTRAK
ANALISIS KOROSI TERHADAP MATERIAL ALMg, SEBAGAI KELONGSONG BAHAN BAKAR RSG-GAS DALAM AIR MENGANDUNG KLORIDA. AIMg 2 adalah salah satu paduan aluminium yang digunakan sebagai bahan kelongsong bahan bakar Reaktor Serbaguna GA. Siwabessy (RSG-GAS) di Serpong, Indonesia. Reaktor ini menggunakan air bebas mineral sebagai pendingin primer dengan $\mathrm{pH}$ 6,5-7,5. Buruknya kondisi air pendingin primer dapat menyebabkan masalah integritas $\mathrm{A} / \mathrm{Mg}_{2}$. Konsentrasi klorida pada pendingin primer harus lebih rendah dari 0.0094 ppm untuk menghindari terjadinya korosi kelongsong bahan bakar. Tujuan dari penelitian ini adalah untuk menentukan pengaruh suhu dan konsentrasi ion klorida terhadap AIMg2. Metode penelitian ini adalah mengamati laju korosi $\mathrm{AlMg}_{2}$ dengan menggunakan Potentiostat. Penelitian dilakukan pada berbagai suhu $\left(28,35,40\right.$ dan $\left.45{ }^{\circ} \mathrm{C}\right)$ dan dalam 0.005, 0.010, 0.015, 0.020, 0,025, 0.030 dan 0.035 ppm natrium klorida. Data hasil penelitian menunjukkan laju korosi $\mathrm{AIMg} 2$ sangat kecil, dan laju korosi tertinggi terjadi pada suhu $45^{\circ} \mathrm{C}$ dalam $0.035 \mathrm{ppm} \mathrm{NaCl}$ yakni $1,23 \times 10^{-3} \mathrm{mpy}$
\end{abstract}

Kata kunci: korosi AlMg, material kelongsong, ion klorida, suhu, Potensiotat.

\section{INTRODUCTION}

$B^{2}$ atan has 3 research reactors. The biggest one is Reaktor Serbaguna GA Siwabessy (RSG-GAS). It has been operated for almost 30 years. The reactor has been operated safely. It is possible the degradation and corrosion process occurred at structure materials and reactor components. The $\mathrm{AlMg}_{2}$ is used as fuel cladding for this reactor. It has its own excellent corrosion resistance and its usage as one of the primary metals of research reactor. It can form itself the oxide layer film that is bonded strongly on its surface. Aluminum has high resistance to corrosion under the majority of service conditions, and no colored salts are formed to stain adjacent surfaces or discolor products with which it comes into contact $[1,2]$.

Corrosion involves the reaction of a metallic material with its environment and it is a natural process in the sense that the metal is attempting to revert to the chemically combined state in which it is almost invariably found in the earth's crust. Corrosion is a natural process that can cause the degradation on material, component and other structures [3]. 
Jurnal Iptek Nuklir Ganendra

Ganendra Journal of Nuclear Science and Technology

Vol. 21 No. 2, Juli 2018: 83-88

The corrosion process can not be able to be stopped. Corrosion can be controlled through many ways; such as, using the material resist to corrosion or controlling the environment. The environment of material has an influence to the integrity of material toward corrosion.

Many type of material are used in nuclear reactor depend on function and environment. Aluminum and its alloy is one of the widely used corrosion-resistant metals. The corrosion rate of aluminum depends mainly on the thickness of the oxide layer and its compactness or crystallographic structure. The corrosion process is also influenced by the electric change of the surface. It is known that the charge on the surface of the oxidized aluminum is the consequence of the interaction of the oxide and the surroundings. The results of the former investigations of the anodic oxidized aluminum have shown that the charge of the surface depends on the oxidation process.

$\mathrm{AlMg}_{2}$ as material cladding has to keep its integrity in order to the reactor can be operated safely. When aluminum surfaces are exposed to the atmosphere, a thin invisible oxide skin forms immediately, this protects the metal from further oxidation. This self-protecting characteristic gives aluminum its high resistance to corrosion. Unless exposed to some substance or condition that destroyed this protective oxide coating, the metal remains fully protected against corrosion [4]. Aluminum is highly resistant to weathering, even in industrial atmospheres that often corrode other metals. It is also corrosion resistant to many acids. Alkalis are among the few substances that attack the oxide skin and therefore are corrosive to aluminum although the metal can safely be used in the presence of certain mild alkalis with the aid of inhibitors, in general, direct contact with alkaline substances should be avoided.

$\mathrm{AlMg}_{2}$ is used in RSG-GAS as cladding material for containing fuel and fission products. Aluminum and its alloys have a good resistance toward corrosion at low temperature and will form a thin oxide film at its surface which separate the metal from its environment and protects from further oxidation. This self-protecting characteristic gives aluminum its high resistance to corrosion. Unless exposed to some substance, such as chloride or condition that destroys this protective oxide coating $[5,6]$. This oxide film can inhibit further corrosion process, but some of them vulnerable to localized corrosion in solution containing chloride. Most of metal and alloys, including aluminum have capability to build passive film from metal oxide. This film will separate the metal from its environments. For aluminum, pit and crevice corrosion are most commonly produced by halide ions, of which chloride $\left(\mathrm{Cl}^{-}\right)$is the most frequently encountered in service [7]. The passive film will be destroyed in environment containing the aggressive ion such as; chloride ion. Temperature also has an effect to corrosion of materials. Increasing temperature is usually followed by increasing corrosion rate $[4,8]$.

$\mathrm{AlMg}_{2}$ degradation can cause an effect to reactor safety. The cladding failure will release radioactive to environment. In research reactors, corrosion processes are strongly affected by operational measured variables such as environment medium, $\mathrm{pH}$, temperature, conductivity and chloride ion content. The protection mechanism to be outlined focuses mainly on maintaining high quality of coolant water.

The RSG-GAS has two coolant systems, i.e. the primary and secondary cooling systems. Both of these systems ensure that the reactor coolant temperature is controlled. During normal operation, heat generated in the core is taken by primary cooling system and transferred to the secondary cooling system via heat exchangers. The heat is discharged into the environment through cooling towers by forced circulation.

Table1. RSG-GAS demineralized water specification [3,9]

\begin{tabular}{ccc}
\hline No & Parameter & Value \\
\hline 1 & pH & $6,5-7,5$ \\
2 & Conductivity (max) & $2 \mu \mathrm{S} / \mathrm{cm}$ \\
3 & Chloride ion (max) & $0,0094 \mathrm{ppm}$ \\
4 & Copper ion (max) & $0,0056 \mathrm{ppm}$ \\
\hline
\end{tabular}

Demineralized water is used for primary coolant and it is produced by demineralized production system that has requirement as noted in Table 1 [9]. The primary cooling system plays an important role in ensuring the integrity and reliability of the fuel cladding that made of $\mathrm{AlMg}_{2}$. The plant's demineralized water system, also known as the GCA01, produces that water. The reactor pool and all subsystems in the primary system are filled by demineralized water, but the secondary system uses freshwater supplied by the utility supplying Puspiptek (the Research Center for Science and Technology, namely the agency which manages the research area where 
the RSG-GAS is located). Prior to use, however, the water from Puspiptek is given mechanical treatment which includes flow through precipitation pools and sand filter pools.

The primary water coolant specification of the RSG GAS is shown in Table 1. The conductivity, chloride ion and copper ion in reactor coolant are very small. Chloride ion as an aggressive ion in small concentration can cause the pitting corrosion. Pitting is a localized form of corrosive attack. Pitting corrosion is typified by the formation of holes or pits on the metal surface. Sometimes pitting corrosion can be quite small on the surface and very large below the surface. Passive metals, such as stainless steel, aluminum and its alloy resist in corrosive media and can perform well over long periods of time [10]. However, if corrosion does occur, it forms randomly in pits. Pitting is most likely to occur in the presence of chloride ions, combined with such depolarizers as oxygen or oxidizing salts $[11,12]$. Aggressive ions such as chloride tend to prevent the formation of protective oxide films on the metal surface and thus increase corrosion [13,14].

Leckie [15] states that the presence of neutral and acid salts in water tends to increase the corrosion rate of iron, steel and low steel alloy by influencing anodic polarization, the conductivity of the solution, the diffusion and solubility of oxygen, and the solubility of the corrosion products.

The purpose of this study is to observe temperature and chloride ion effect to $\mathrm{AlMg}_{2} \mathrm{RSG}-\mathrm{GAS}$ cladding material. The method that used in this research is to observe the corrosion rates of $\mathrm{AlMg}_{2}$ material in $\mathrm{NaCl}$ concentration at several temperature conditions using Potentiostat. Tests were conducted in 28, 30, 35, 40 and $45{ }^{\circ} \mathrm{C}$. The RSG - GAS cooling water temperature in normal operation is around $40{ }^{\circ} \mathrm{C}$. The $\mathrm{AlMg}_{2}$ corrodes in solution containing $\mathrm{NaCl}$ solution. The chloride ion content of the water should be maintained as low as achievable and at less than $0.0094 \mathrm{ppm}$ for optimum corrosion protection. The chloride ion in cooling water is possible come from the water make - up system. Chloride ions break down the passive film on aluminum and promote metal dissolution. The chloride ions in these chemicals in small amount will destroy the passive film on aluminum and cause aggressive pitting corrosion. The corrosion process of aluminum increases with increasing temperature. Corrosion resistance is used as criterion in determining the lifetime of components and structures. The aim of this research is to determine the corrosion of $\mathrm{AlMg}_{2}$, based on corrosion rate in various $\mathrm{NaCl}$ cocentrations and temperatures. The experiment used electrochemical method by using Potentiostat.

\section{METHODOLOGY}

\section{Specimen Preparation}

$\mathrm{AlMg}_{2}$ was used as specimen in this experiment. The specimen dimension is $10 \mathrm{~mm}$ of length, $10 \mathrm{~mm}$ of width and $5 \mathrm{~mm}$ of thickness. The specimen surface was treated with polished paper from grade $400,600,800$ and 1000 and then polished with Metadi II diamond paste

\section{Corrosion Test Using Potentiostat}

Anodic polarization was obtained by a potential scanning from $-500 \mathrm{mV}$ at an open circuit potential (OCP) to $600 \mathrm{mV}$ OCP at a rate of $0.2 \mathrm{mV} / \mathrm{sec}$. A silver/silver chloride $(\mathrm{Ag} / \mathrm{AgCl})$ and $\mathrm{Pt}$ wire were used as reference electrode and a counter electrode, respectively. For each condition, temperature was changed to simulate the corrosion testing. Corrosion testing was conducted in various temperatures $\left(28,35,40\right.$ and $\left.45^{\circ} \mathrm{C}\right)$ and in 0.005 , $0.010,0.015,0.020,0.025,0.030$ and $0.035 \mathrm{ppm}$ of sodium chloride concentrations. The demineralized water with $\mathrm{pH}$ of 6.7 and conductivity $0.4 \mu \mathrm{S} / \mathrm{cm}$ was used in the experiment.

\section{Data Analysis}

Corrosion current that find from the experiment was analyzed by using Tafel slope analysis to get corrosion rate. Tafel analysis is performed by extrapolating the linear portions of a logarithmic current versus potential plot back to their intersection. The value of either the anodic or cathodic current at the intersection is $I_{\text {corr. }}$. Corrosion rate is calculated by using equation (1).

$$
C_{r}=\frac{I_{c o r r} K \cdot E_{w}}{d \cdot A}
$$

Where $I_{\text {corr }}$ is a corrosion current in Ampere, $\mathrm{K}$ is a contant that defines by the units in corrosion rate, $E_{w}$ is equivalent weight in gram/equivalent, $\mathrm{d}$ is density in gram $/ \mathrm{cm}^{3}$, and $\mathrm{A}$ is sample area in $\mathrm{cm}^{2}$ [15]. 
Jurnal Iptek Nuklir Ganendra

Ganendra Journal of Nuclear Science and Technology

Vol. 21 No. 2, Juli 2018: 83-88

\section{RESULT AND DISCUSSION}

\section{Temperature Effect to $\mathrm{AlMg}_{2}$ Corrossion}

Almost all of chemistry reaction rate will increase linearly with temperature. At high temperature increasing of the corrosion rate is accelerating by oxygen diffusion to the system. In open vessel, where the oxygen is free to escape, the corrosion rate increases with temperature up to $80^{\circ} \mathrm{C}$. Then, as the temperature is increased further, the corrosion rate decrease. This is due to a drop in the oxygen solubility of water above $80{ }^{\circ} \mathrm{C}$. In closed system, oxygen cannot escape, and the corrosion rate increase with temperature until all of the oxygen is consumed. The rate of diffusion of oxygen increases with rise in temperature. However, owing to the reduction in the solubility of oxygen with rise in temperature, the curves expressing the relation of the rates of corrosion of the above metals to temperature show maxima. The limiting diffusion current varies with temperature in a similar way. It would be expected that in a "closed system" both the limiting diffusion current and the rate of corrosion processes controlled by diffusion would rise continuously with increasing temperature.

This would explain that the temperature dependence of the corrosion rate shown in Fig. 1 as well as its dependence on $\mathrm{NaCl}$ concentration. For a thermally activated process, corrosion rates are expected to increase with increasing temperature. Increasing the corrosion rate also occur at temperature $28^{\circ} \mathrm{C}, 40^{\circ} \mathrm{C}$ and $45^{\circ} \mathrm{C}$ with increasing $\mathrm{NaCl}$ concentration.

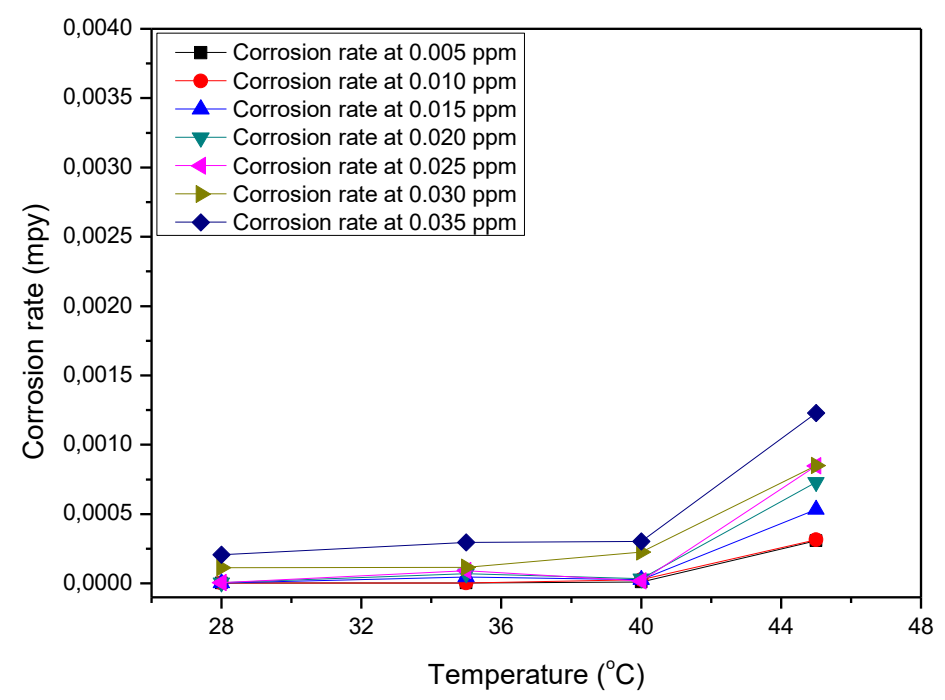

Figure 1. $\mathrm{AlMg}_{2}$ corrosion rate at various temperatures in several $\mathrm{NaCl}$ concentrations in demineralized water with $\mathrm{pH} 6.7$ and conductivity $0.4 \mu \mathrm{S} / \mathrm{cm}$

\section{Effect of $\mathrm{NaCl}$ Concentration on $\mathrm{AlMg}_{2}$ alloy Corrosion Rate}

The Table 2 shows experiment results that $\mathrm{NaCl}$ addition tend to increase $\mathrm{AlMg}_{2}$ corrosion rate. At temperature $35^{\circ} \mathrm{C}$ in $0.005 \mathrm{ppm} \mathrm{NaCl}$, corrosion rate is $2.63 \times 10^{-6}$ and increases to $3.21 \times 10^{-6} \mathrm{mpy}$ in $0.010 \mathrm{ppm}$ $\mathrm{NaCl}$, at the same temperature. Then at the same $\left(35^{\circ} \mathrm{C}\right), \mathrm{AlMg}_{2}$ corrosion rate in $0.015 \mathrm{ppm} \mathrm{NaCl}$ is $4.59 \times 10^{-6}$ mpy and increase become $7.12 \times 10^{-6} \mathrm{mpy}$ in $0.020 \mathrm{ppm} \mathrm{NaCl}$. At the same condition $\left(35^{\circ} \mathrm{C}\right)$, corrosion rate continue to increase with increasing $\mathrm{NaCl}$ concentration, for example; is $2.96 \times 10^{-4} \mathrm{mpy}$ in $0.035 \mathrm{ppm} \mathrm{NaCl}$. Chloride as an aggressive ion can destroy the passive film on the alloys and metal surface. Many metal and alloys have an ability to form the passive film from metal oxide which separated metal from its media. Herefore ion chloride concentrations determine the incubation time of pitting corrosion. Ion chloride and oxygen will compete to be adsorbed at material surface. The higher the ion chloride concentration is the higher possibility chloride ion to be absorbed at material surface. It can be seen at Figure 2, since $0.030 \mathrm{ppm} \mathrm{NaCl}$ concentration, $\mathrm{AlMg}_{2}$ corrosion rate increase sharply. 
Table 2. $\mathrm{AlMg}_{2}$ corrosion rate at several temperatures and $\mathrm{NaCl}$ Addition in outlet Mix Bed water ( $\left.\mathrm{pH} 6.7\right)$ and conductivity $0.4 \mu \mathrm{S} / \mathrm{cm}$

\begin{tabular}{llllllll}
\hline $\begin{array}{l}\text { Temp } \\
\left({ }^{\circ} \mathrm{C}\right)\end{array}$ & \multicolumn{6}{l}{ Corrosion rate (mpy) at various NaCl Concentration (ppm) } \\
\hline 28 & 0.005 & 0.010 & 0.015 & 0.020 & 0.025 & 0.030 & 0.035 \\
\hline $2.08 \times 10^{-6}$ & $2.61 \times 10^{-6}$ & $2.70 \times 10^{-6}$ & $4.59 \times 10^{-6}$ & $6.63 \times 10^{-6}$ & $1.14 \times 10^{-4}$ & $2.06 \times 10^{-4}$ \\
35 & $2.63 \times 10^{-6}$ & $3.21 \times 10^{-6}$ & $4.59 \times 10^{-5}$ & $7.12 \times 10^{-5}$ & $9.08 \times 10^{-5}$ & $1.15 \times 10^{-4}$ & $2.96 \times 10^{-4}$ \\
40 & $9.56 \times 10^{-6}$ & $2.63 \times 10^{-5}$ & $2.70 \times 10^{-5}$ & $3.36 \times 10^{-5}$ & $1.77 \times 10^{-5}$ & $2.26 \times 10^{-4}$ & $3.03 \times 10^{-4}$ \\
45 & $3.09 \times 10^{-4}$ & $3.15 \times 10^{-4}$ & $5.34 \times 10^{-4}$ & $7.30 \times 10^{-4}$ & $8.47 \times 10^{-4}$ & $8.51 \times 10^{-4}$ & $1.23 \times 10^{-3}$ \\
\hline
\end{tabular}

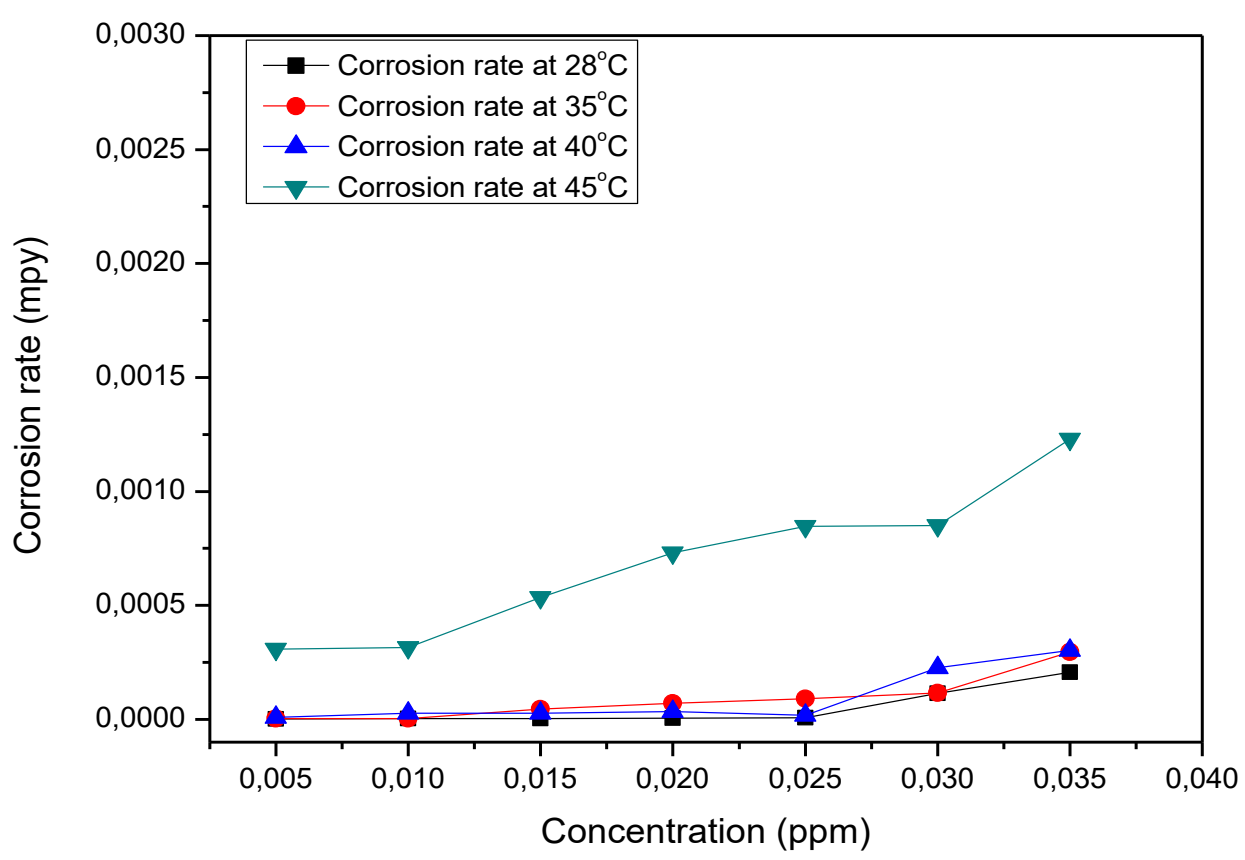

Figure 2. $\mathrm{AlMg}_{2}$ corrosion rate in various $\mathrm{NaCl}$ concentrations at various temperatures in demineralized water with $\mathrm{pH} 6.7$ and conductivity $0.4 \mu \mathrm{S} / \mathrm{cm}$

\section{CONCLUSION}

The laboratory experiment result showed the relation between increasing temperature and corrosion rate. From the Tafel slope analysis, it can be seen that $\mathrm{NaCl}$ addition into solution affected to $\mathrm{AlMg}_{2}$ corrosion rate. At higher $\mathrm{NaCl}$ concentration that added in the solution will affect the higher corrosion rate of $\mathrm{AlMg}_{2}$. The result of experiment shows that the highest corrosion rate occur in $\mathrm{NaCl} 0.035 \mathrm{ppm}$ solution at temperatur $45{ }^{\circ} \mathrm{C}, 1.23 \times 10^{-3}$ mpy. From the $\mathrm{AlMg}_{2}$ corrosion rate data, it was found that $\mathrm{NaCl}$ can cause corrosion to $\mathrm{AlMg}_{2}$ as fuel cladding. The corrosion rate of $\mathrm{AlMg}_{2}$ as fuel cladding material is very small in all of experiment conditions. The corrosion resistance material is important requirement for material that used in nuclear reactor. Ion chloride consentration has been controlled in tightly to ensure the reactor safety.

\section{ACKNOWLEDGEMENT}

This work has been carried out under Center for Nuclear Reactor Technology and Safety (PTKRN) in the year of 2017 budget program, National Nuclear Energy Agency of Indonesia (BATAN). The authors appreciate thank you very much to the research coordinator of "Ageing of RSG GAS" for her support. 


\section{REFERENCES}

[1]. J. Malina, J Radosevic, "Influence of $\mathrm{NaCl}$ concentration on pitting corrosion of extruded Al-Mg-Si alloy AA6060". Zastita Materijala, vol. 56, no. 4, pp 47 - 50, 2015

[2]. Marzieh Kishan Roodbari, Effect of microstructure on the performance of corrosion resistant alloys, Norwegian University of Science and Technology. Dept. Materials Science and Engineering, 2015

[3]. Sriyono, Rahayu K, Abdul Hafid, Sofia Loren B, Geni Rina Sunaryo, "The debris particles analysis of RSG GAS to anticipate sediment induced corrosion", Jurnal Pengembangan Energi Nuklir, Volume 18, No. 1 pp 8-14, 2016

[4]. J. Soltis, , N. J. Laycock, D. Krouse, "Temperature dependence of the pitting potential of high purity aluminum in chloride containing solutions", Corr. Sci., vol. 53, no. 6, pp 7-10, 2014

[5]. R. S. Rana, Rajesh Purohit, and S Das, "Reviews on the influences of alloying elements on the microstructure and mechanical properties of aluminum alloys and aluminum alloy composites" International Journal of Scientific and Research Publications, Vol 2, pp 6-11, 2012

[6]. Ahmad Almansour, MazenAzizi, Abdul Munem Jesri, "Sami Entakly Effect of deformation processes on corrosion behavior of AA6061 in salt solution (3.5\% NaCl)", IJASR International Journal of Academic and Scientific, vol 2, no.4, pp 71-77, 2014

[7]. Kunio Shobara, "The Effect of Halide lons on the Pitting and Crevice Corrosion of Austenitic Stainless Steels", Journal of Corrosion Engineering, Volume 24, Issue 9, pp 453-457, 2015

[8]. Radošević, J. Malina, N. Dolić, P. Ljumović, Slavica - Matešić S. "Susceptibility to corrosion of welded AlMgSi alloy EN AW 6060", Zastita materijala, vol. 54, no. 1, pp 3-7, 201

[9]. Dyah E.L., "Current status of RSG GAS water chemistry", Proceeding of Training Course. on Water Chemistry of Nuclear Reactor System 3, November pp 13-17, 2006

[10]. A. A. Mashar, S.T. Arab, E. A. Noor, "The role of chloride ion and pH in corrosion and pitting of Al-Si alloys", Journal of Applied Electrochemistry vol. 2, no. 31, pp 1131-1140, 2011

[11]. Febrianto, "Analisis fluktuasi arus korosi saat hancurnya lapisan pasif dan repasifasi oleh ion klorida", Prosiding Seminar Nasional ke-15 Teknologi dan Keselamatan PLTN Serta Fasilitas Nuklir, ISSN : 08542910 Surakarta, 2009

[12]. M. Trueba, S. P. Trasatti, "Study of Al alloy corrosion in neutral $\mathrm{NaCl}$ by the pitting scan technique", Mat. Chem. Physics, vol. 3, no. 121, pp 523-533, 2010

[13]. Y. Solhan, F.R. Afidah, "Inhibitive behaviour of corrosion of aluminum alloy in $\mathrm{NaCl}$ by Mangrove Tannin". Journal of Sains, Malaysia vol. 40, no. 9, pp 953-957, 2017

[14]. Zaid, D. Saidi, A. Benzaid, S. Hadji, "Effects of $\mathrm{pH}$ and chloride concentration on pitting corrosion of AA6061 aluminum alloy", Corr. Sci. vol. 50, no. 4, pp 54-60, 2008

[15]. H. P. Leckie, Iron, Carbon steel, and low alloys steel in the process industries, Process Industries Corrosion, Natl. Assc. of Corrosion Engineers, Houston, USA, pp 90-95, 1975 